\title{
Performance Evaluation of Stock Markets
}

\author{
Alina Kvietkauskiené ${ }^{1}$, Raimonda Martinkutè-Kauliené ${ }^{2}$ \\ Department of Finance Engineering, Faculty of Business Management, \\ Vilnius Gediminas Technical University, Vilnius, Lithuania \\ E-mails: '1alina.kvietkauskiene@vgtu.lt (corresponding author); ${ }^{2}$ raimonda.martinkute@vgtu.lt
}

Received 19 February 2017; accepted 05 April 2017

\begin{abstract}
The authors concentrate their attention on the performance evaluation of stock markets. The markets evaluation and selection is the important part of investment decision making. In order to develop a conceptual framework for investment decisions in financial markets, it is important to establish a logical model for market selection. The main purpose of the article - to propose the scheme of stock market evaluation and selection for investment portfolio formation. The authors propose the scheme, according to that, it is possible to analyse the issue of the market value and to select markets that may potentially generate a sustainable investment return for investor, taking into account that sustainable investment return is the stable investment return for a long period. According to the analysis of selected stock markets and their evaluation using three-dimension utility function, the authors identified the most stable markets to investors for investment portfolio formation.
\end{abstract}

Keywords: stock market, utility function, market evaluation, investment decisions, sustainable return.

JEL Classification: G1, G11, G14, G17.

Conference topic: Contemporary Financial Management.

\section{Introduction}

The main role of stock markets is to ensure capital allocation function can not be underestimated in today's environment. At the end of 2015 years, the total world stock market capitalization was 54.57 trillion dollars, which in turn generates about $76 \%$ of the world's gross GDP, which means the stock market plays an important role in global economic development.

Every stock market is closely related to the country economy; therefore, the development of its relationship with the country's economic development is reciprocal, because the general improvement in the economic situation together doing more active and the stock market, on the other hand, the development of the securities market, accelerates the country's economic growth. It is estimated that after falling in share prices, we can expect economic stagnation and vice versa, rising stock prices is a sign of potential growth.

Widely is known view that from behaviour of financial markets can deal with the country economic condition. Financial markets show the companies' opinion about the behaviour of national economy in the near future than the most directly exposed, i.e., stock prices are caused by investors' expectations. For this reason usually is examined changes in the stock price, as they reflect the changing economic situation.

Therefore investors frequently change their movement direction of the shares not only observing the equity markets, but also the macroeconomic situation in the country: followed policy of Federal Reserve Bank, public speeches by Central Bank representatives, forecasts of World Bank, even the problems in Greece has influence on stock market situation and investor decisions.

According to the fast change and growth of the financial markets, it becomes necessary to create or to select right tools that help investors make their investment decisions and correctly select assets to investment portfolio in order to achieve significant investment return and avoid risk. Price forecast as well as the right time to buy or to sell the stocks is much discussed topic by investors.

Due to their functions in the economy, the stock markets in modern conditions of globalization is becoming very attractive to investors. There is a need to form a potential market selection algorithm, which using investors will be able to form investment portfolios in different stock markets.

The object of the article is the evaluation of stock markets.

(C) 2017 A. Kvietkauskienė, R. Martinkutè-Kaulienè. Published by VGTU Press. This is an open-access article distributed under the terms of the Creative Commons Attribution (CC BY 4.0) License, which permits unrestricted use, distribution, and reproduction in any medium, provided the original author and source are credited. 
The main goal of the article is to propose the scheme of stock market evaluation and selection for investment portfolio formation.

The main objectives highlighted to achieve the purpose of the article:

- to perform the analysis of the methods and measures of financial market evaluation;

- to form the scheme of market selection and evaluation;

- to perform selected global stock markets analysis and assessment;

- to submit the conclusions and suggestions.

Research methods: analysis of primary sources, the study of secondary data and scientific literature, utility function, market simulacion, graphical data representation.

\section{The methods and measures of financial market evaluation}

The main purpose of every financial market is to orient towards activities, oriented to economic and social advance. In this way, the main goal for investors is to get higher profit with lower risk. There are main economic theories that analyse market behaviour and help to choice the best financial market for further investment decisions.

One of the most used is method for financial analysis - technical analysis that is based on the hypothesis that past price tends to repeat itself in the future (Gorgulho et al. 2011). Technical analysis is a wide term that includes the usage of a range of trading strategies in global financial markets (Masry 2017). This method firstly was used by the Japanese rice dealers, which were selling futures contracts (called future), 300 years ago. Afterwards, the Japanese used price prediction method was called "Japanese candles" (Шевченко 2001).

Kirkpatrik and Dahlquist (2016) define technical analysis as the analysis of historical market data, principally volume data and price changes. All this collected information is used to make investment decisions or trading.

For technical analysis, the most important are short-term and psychological factors. This analysis can be applied for the financial instruments that are traded in the market and which have the changing market price, but in most cases it is applicable for stocks, currencies, commodities, futures and options markets.

There is excluded a group of technical factors that determine the price of stocks. These factors are related to market conditions, taking into account changes in prices, demand and supply factors and trading turnover. The data obtained are represented in graphs. Studying charts, the analytics of technical analysis seek to measure the time of securities buying and sale in order to anticipate market volatility: the need to buy before the market take-off (called upswing) and sell - before the market drop (called the downswing). These graphics are widely used in the compilation of the stock market averages and indexes, as well as identifying individual stock and commodity prices (Cibulskiené, Grigaliūnienè 2006).

Technical analysis can be represented and interpreted in accordance with the following scheme (see Fig. 1). The most important and best-known technical analysis theories are submitted in Figure 1.

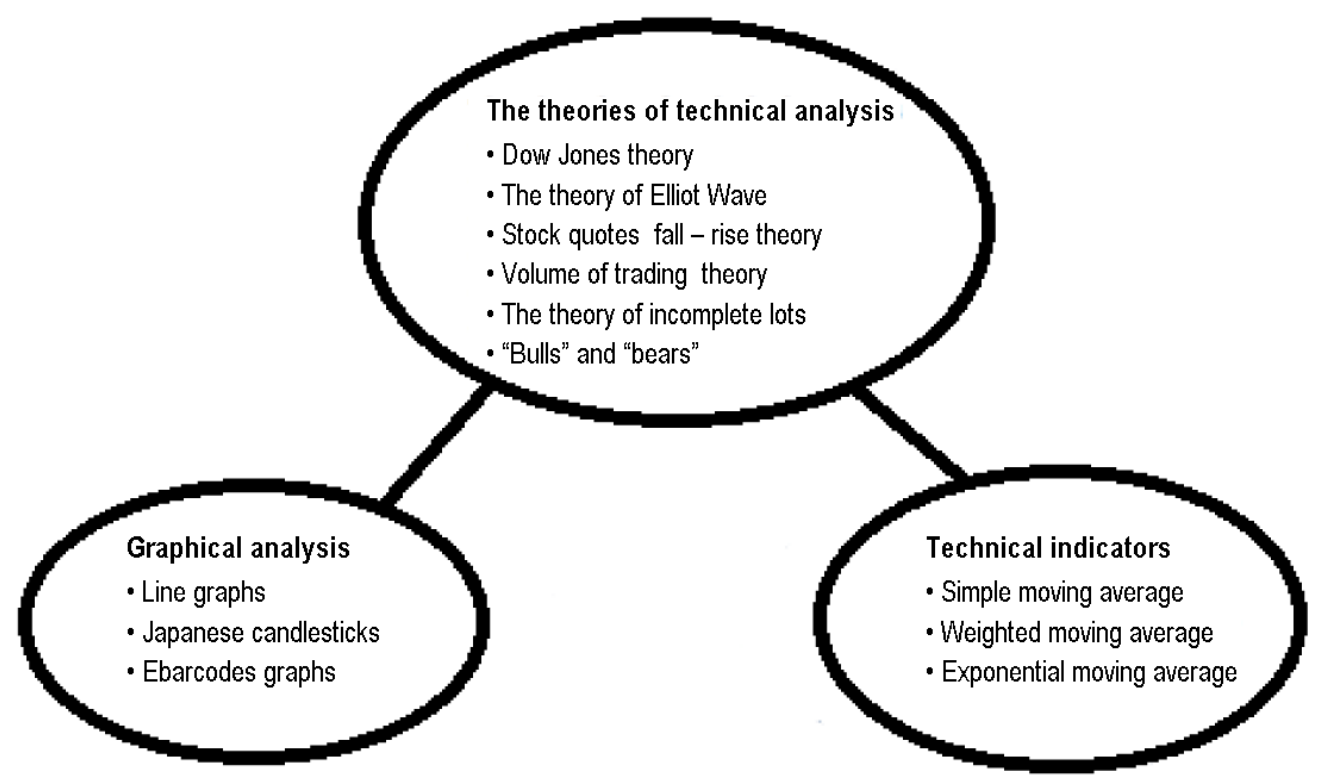

Fig. 1. The scheme of technical analysis (Source: compiled by authors) 
One of the positive aspects of this analysis is the fact that it allows to predict short-term stock market price fluctuations. The portrayal of stock prices change graphically gives valuable information on market prices and future dynamics.

Whereas the technical analysis is performed in accordance with statistical analysis, assuming that the stock prices of past determines the future prices, and only the internal market information, it is because in some cases it may be inaccurate because of the need to take into account many other factors influencing market behaviour.

According to Narayan et al. (2013) technical analysis lacks a theoretical motication. After technical analysis, there are only receiving information about the evolution of market prices and the possible dynamics, but, in authors opinion, it is not enough to develop an effective investment strategy.

Fundamental analysis is another type of analysis, also used by investors, that pays attention at macro indicators or the balance sheet of the listed companies (Daniel et al. 2017). Fundamental analysis involves audit reports, financial statements, management capabilities and stock's rate of return, beta coefficient and other return and risk parameters (Bayramoglu, Hamzacebi 2016; Albadvi et al. 2007).

Fundamental analysis is the basis of the general economic situation and development of the country factors evaluation. The results provide the opportunity to evaluate the companies or investment attractiveness. Fundamental analysis is used to determine the course of variable stocks prices. This analysis done in three stages:

1) national economic analysis of the situation;

2) industry analysis;

3) analysis of the company.

Analysing the economic situation, it is possible to determine whether the situation in the market is appropriate for investment. Negative macroeconomic effects result in expected profits and the assumed degree of risk regardless of a diversified portfolio. The industry analysis takes into account the relative weight of the single branch of the economy, the life-cycle stage. There is a comparison by branches of economy sales and profit growth trends, the level of competition. The classifications of industries are invoked at this stage.

There are distinguished:

- Growing economic sectors that are characterized by sales and earnings growth in the future in spite of the economic cycle. Growing industries are classified as those, which are in the introduction phase, and traditional industries, existing in growth stage due to newly introduced technology and the transition to innovative products. Investments in stocks of this industry are characterized by high profitability and potentially high percentage of the price drop.

- Security, branch of economy characterized by their operational stability. These industries are the least exposed to the macroeconomic situation, so sales volumes and profit margins are relatively stable even during an economic downturn. Although the stable situation of branch can not guarantee protection against the falls of quotes risk, but the risk will be lower than the growth of industries.

- Cyclic branch of economy mainly depends on the stage of economic development: when the economy arises, they are also experiencing growth, during the economic downturn - they are experiencing decline.

The third stage of fundamental analysis evaluate separate companies and their securities. This analysis is used to calculate liquidity, solvency, efficiency, profitability, and other indicators of the company. The annual and quarterly reports of companies, the publications, contained in print and on websites, the information collected by shareholders and public speeches of companies' executives and the information of special studies conducted by market participants are used for this analysis.

Therefore, it can be observed one lack of analysis: the accuracy of analysis depends on the transparency of used information. Furthermore, using this analysis method, it can only be assessed attractiveness of investments; it is not clear under what criteria it is need to choose the most suitable investment market. This analysis allows to determine whether situation in the market is suitable for the investment, but do not allow to assess which markets will be the most attractive in terms of investment. According to Silva et al. (2015), some investors believe that they can overcome the market using fundamental or technical analysis.

Other method used for market evaluation is Efficient market hypothesis (further - EMH), proposed by Fama (1965). The main idea of this method is that a stock market is active, there are well informed, and prepared investors, who evaluate stocks, based on all available information.

Thus, the prices in effective market reflect the impact of the information relating to events that occurred in the past, and information related to the events that may happen in the near future. Due to the competition between the advanced players of efficient market, it is assumed that the actual price of the security is a bit consistent with the fair value at any time. If the market is efficient, in this case any available information or analysis does not earn more than earn any selected index. However, there is a variety of evidence to find more "anomalies" in the international stock markets, which are usually caused by doubts about the efficient market hypothesis (Mittal, Jain 2009).

Over the years, many scientists and academics studied the stock market behavior, involving every developed and emerging economies in order to have a clear understanding of the market efficiency and thus raised a number interesting questions, which are still applied in considerable debates. The performance of various studies throughout the world (Jeffrey, Westerfield 1989; Stickel 1995; Womack 1996) found that stock returns were not completely random, and various anomalies, such as a weekend effect, a day-of-the-week effect and others exist in the markets. On the other 
hand, some studies (Steeley 2001) shows that these "anomalies" tend to disappear over time, and therefore it can be concluded that the market is efficient (Mittal, Jain 2009).

For each market participants is important to understand the importance of EMH in two cases - when the market is efficient and inefficient. Previous described technical analysis is the completely opposite to EMH. Technical analysis suggests that the prices of financial instruments vary according to trends that persist over time. Meanwhile, the efficient market hypothesis submits that the price and volume data are already reflected in prices. Investors who accept EMH try to form portfolios that optimally diversify risk or assimilate the market. However, investors who use technical analysis try to regularly beat the market via revealing inefficiencies in market structure (Masry 2017).

Fundamental analysis suggests that investors from received the same data may have different conclusions, and if one of the conclusionis better than any other, so he can get a higher profit. It would appear that both of these theories have nothing common but the fact that some investors do not believe in EMH, help the market to be efficient. After all, fundamental analysis is performed on a daily basis and is reflected in prices.

Generalizing the empirical research and theoretical fundamentals, Eugene F. Fama (1970) identified three forms of market efficiency in his works: weak, semi-strong and strong form of efficient market.

- Weak form is the part of the efficient market theory, which claims that market prices reflect all historical price and volume data - market data. It is explained that the market data are already made an impact on the current price and therefore there is no relevance prediction of future price changes. Because market data commonly used in technical analysis and therefore the forecasts of technical analysis are of little value. Utility tests of price and volume called the weak form of efficient market research. Price and volume data utility tests called the weak form of efficient market research. If it is confirmed, that the form of the efficient market is weak, so changes of past price are not associated with future price movements. Then they take place independently and the attempt to trade in these markets, based on experience and historical data and trends, will fail. Rutkauskas (2000) describes the efficiency of weak form as the market, which do not have "memory" and the fluctuation curve of security price is called random.

-Semi-strong form - one of the efficient market theory parts, describing the fact that the market price reflects not only the historical price and volume data, but also all publicly available information - information on the distribution of shares, the profits of the issuer, dividends, financing problems, accounting changes and liquidity. It is important to note that the semi-strong form includes a weak form because it owns market data and publicly available information. Based on public information, investors in such market will not be able to get a higher profit than average profit because the price already reflects new public information.

- Strong form of market efficiency is observed when market prices reflect all information (public and nonpublic). Non-public information is usually available only to the issuer related persons (directors, officers, shareholders who have more than 10 percent shares) and relevant market professionals. If an efficient market is strong form, investors can not within a certain time to get the excess profit, taking advantage of the price affecting the information. Professionally managed portfolios commonly are tested by this approach. According to strong form of the efficient market theory it can be said that stock prices immediately adapts to the all information. The analysis of market behavior takes into account certain ongoing market anomalies because not all evidence supports the EMH. In particular, the main evidence against market efficiency is:

- Small firm effect or "size effect". Banz (1981) argued that the effect of small businesses is one of the longest preserved anomalies. The size effect is the expected return of apparent abundance, which is growing for small capitalization companies shares, under excess risk in these companies. Stock returns of small company directly correlated with the risk, therefore any investment in stocks can get better returns, but the risk is much higher comparing to large companies. The reason behind this could be that turnover of small enterprises are less, less attention of investors and therefore risk is not assessed accurately. It would be difficult to explain this effect solely based on risk assessment. There is observed a significant correlation between the stock price in the market and single average price of shares. The stock price of small company is lower than the price of big corporations. Under ordinary commercial trade, transaction costs of stocks for small businesses are proportionally higher. Nevertheless, the effect of small companies is not stable and is often observed in the reverse pattern.

- "January" effect. Firm size effect mainly occurs, in the month of January, and from that half of size during the first five trading days. There have been attempts to explain this due to the tax paid at the end of December, the prices temporarily fallen, and rose again in January. However, such interpretation does not have compelling evidence. Keim (1983), Roll (1983), Rozeff and Kinney (1976) justified the seasonal anomalies as follows: small capitalization stocks tend to surpass the large capitalization stocks by a wide margin in a calendar year. This so-called "January effect" looks strong during the review period and this is difficult to reconcile with the efficient market hypothesis on the regularity and publicity.

Effect is clearly manifested in the seasonal trends in the market. Stocks, which have negative returns throughout the year, in the month of December have a higher circulation (with a positive return decrease), but in January the following shares, which had negative returns last year, had an additional return. January effect - a month characterized 
by growth of prices due to the fact that investors sell the unprofitable shares in December, in order to create maximum tax-free profits.

In orther literature the impact of deregulations on financial market efficiency is analysed (Kim, Singal 2002; Ataullah et al. 2004; Cajueiro et al. 2009; Bae et al. 2012; Hooy, Lim 2013). Most financial analysts and researchers adopt a weak form, reject a strong form and believe that in the most cases the market has semi-strong form. Of course, there are exceptional cases when the market is inefficient. Going to the financial market immediately is faced with uncertainty, which must be taken into account when taking investment decisions, but in the concept of EMH does not touch on the uncertainty in the decision of that fundamental value does not reflect market value. In view of this observation, the authors made a decision that this method is not entirely suitable for the selection of perspective markets for investment.

\section{The usage of utility function for financial markets evaluation}

The selection of multicriteria feature and evaluation of opportunities practical applications are very important problems, which particularly receive strong emphasis on mathematics, mechanics and other "quantitative" science. However, the attention should be paid to social sciences problems, where a large part of the factors examined only qualitatively and therefore direct analysis of multicriteria causes many questions (Rutkauskas, Stasytytė 2011).

In this work in order to explore and identify the opportunities, which the market offers for investors, the approach from previous authors researches was used (Rutkauskas, Kvietkauskiene 2012) taking into account that the rate of return stand on financial assets is possibilities probability distribution.

Rutkauskas (2000) explained that investment portfolio decisions should be achieved when it is possible to describe the profit possibilities of portfolio as their probability distribution. He first proposed the idea of adequate portholio theory, which essence is assessment of investment portfolio risk, profitability and reliability. The choice of investor should be moved into a three-dimensional plane, where the portfolio risk is deferred in abscissa, portfolio profitability possibilities - in ordinate, and the third characteristic - the portfolio profitability reliability - in coordinate (Rutkauskas 2000). Utility function is also concluded according to the same parameters, which describe Rutkauskas (2000) in proposed adequate portfolio theory.

In order to effectively allocate available resources in the financial markets, it is important to identify the opportunities offered by the markets, profitability and risk level - in this way markets will be selected, where investors, by taking the appropriate level of risk, will receive the complex of utility and reliability.

In this case, in order to achieve successful investment decisions, it should appeal to the survival function, which would allow evaluating each market offered opportunity by the size of possibility and guarantee of this size. This scheme will enable quicker, than with all other models and methods, review market opportunities. The choice of useful options for investor is associated with equivalent recovery of utility function.

Whereas the utility is associated with efficiency, reliability and risk, it is possible to invoke the utility function:

$$
U=\frac{f(e) \times f(p)}{f(r)},
$$

where: $f(e)$ - efficiency; $f(p)$ - reliability; $f(r)$ - risk.

The circumstances, that affect the possibility with highest probability and possibility with highest efficiency distribution, are two. It is understood that possibility with highest probability is conditioned of objective market conditions and the possibility with highest utility - it is the investor expression of objectives and characteristics. Therefore, the parameters of mentioned layout should be a very important argument in choosing financial markets for futher investment decisions.

In view of already existing markets possibilities probability distributions, it can be continued further market analysis. Since the possibilities probability distribution of profitability and utility function of each market shows only what the market offers for investors and what is useful, but not necessarily, the option with the highest probability will be most useful, it should be examined to find which option is the best if it was considered to its size and reliability.

In order to select the utility function, which is actually the most useful, it is necessary to take into account the profitability and reliability. Utility function depends on the efficiency and reliability, and reliability is associated with risk, so from the available data are calculated so-called survival function. Based on calculations and diagrams each market can be ranked according to the investor's utility function approach.

As one of the methods, used for the most attractive market selection, authors use utility function.

\section{The scheme of market selection}

In order to develop a conceptual framework for investment decisions in stock markets, it is important to establish a logical model for market selection (see Fig. 2). Short description for each phase of model: 
- Basic market evaluation. The aim of this phase - to choose the long period for market analysis and to compare markets according to their capitalization, turnover ratio (\%) and number of listed companies.

- Global choice of markets for testing - financial market selection and identification based on the previous done basic market evaluation.

- Market assessment (profitability, risk). The aim of this phase - to analyse the estimates of profitability and risk of appropriate financial markets; to accomplish the comparison of results in different periods.

- Adaptation of utility function for evaluation of opportunities offered by market. The aim - to determine the possibilities, which the market offer for investor, by using modelling of financial markets.

-Identification of probability distribution of the market. It is important to identify the possibilities probability distribution that will be the ground for further market analysis - determining the survival and utility function.

- Feasibility study of market. The application of survival function should allow assessing the opportunities, offered by market.

- Utility, profitability, reliability, risk. These indicators should be identified at the time of evaluation utility function. It should be done the markets ranking, processing and assessing the utility, reliability, profitability and riskiness.

- Summary of test results. The aim - to rationaly estimate all the previous obtained results.

- Approbation of financial markets. In this stage should be identified the structure of selected markets for further investment.

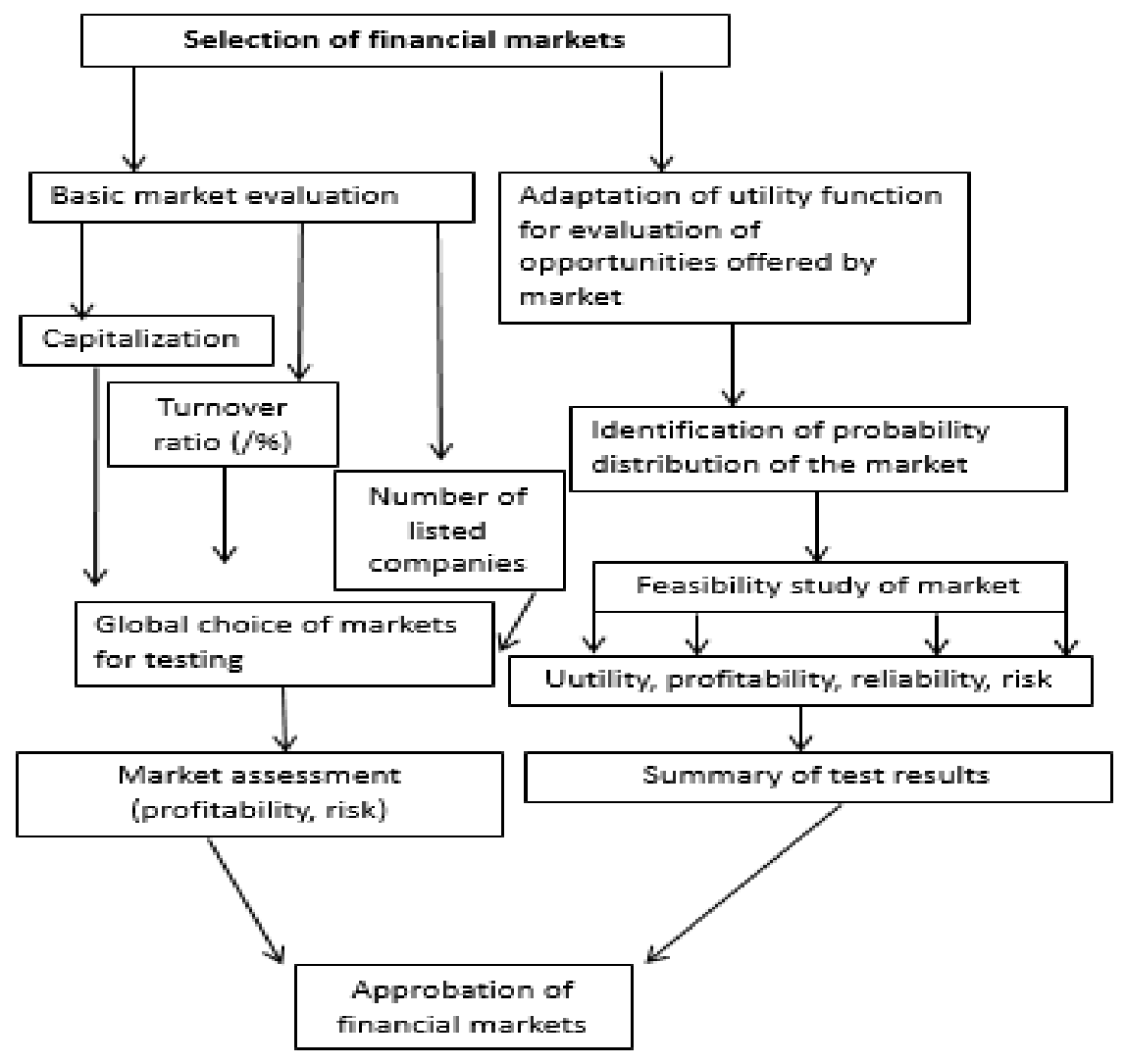

Fig. 2. The model for market selection

(Source: prepared by the authors)

According to that the scheme developed by the authors, it is possible to analyse the issue of the market value and to select markets that may potentially generate a sustainable investment return for every investor. Sustainable investment return means the stable investment return in long period.

33 major global stock markets belonging to the American, European, Asian and Australian continents (see Table 1) were selected for the analysis.

Historical data of 10 years was used. Table 1 shows the analyzed market capitalization (\% of GDP) for the period of 1995-2015. Markets were ranked from highest to lowest market capitalization in 2015 years. It can be seen that until the market value decrease that occurred in 2011, most of the markets showed the growth, associated with the country's GDP growth. The biggest growth in the analyzed period observed in Hong Kong and Switzerland markets, 
particularly since 2010. Relatively stable growth trend observed in the United States of America (USA), Dutch and Norwegian markets. The lowest market growth observed in Ukraine, Slovakia, Macedonia, Bulgaria and Cyprus markets.

Table 1. Market capitalization of listed companies (\% of GDP)

(Source: prepared by the authors, according to World Bank data 2016)

\begin{tabular}{|c|c|c|c|c|c|}
\hline Market capitalization of listed companies (\% of GDP) & 1995 & 2000 & 2005 & 2010 & 2015 \\
\hline Hong Kong, China & 209.95 & 363.14 & 581.04 & 1185.86 & 1027.61 \\
\hline Switzerland & 116.49 & 291.66 & 230.34 & 211.52 & 228.56 \\
\hline Finland & 32.89 & 233.90 & n.a.* & n.a.* & 178.60 \\
\hline United States & 90.71 & 146.89 & 129.84 & 115.50 & 139.68 \\
\hline United Kingdom & 107.46 & 165.74 & 126.43 & 110.71 & 127.59 \\
\hline World average & 68.53 & 104.06 & 93.21 & 86.85 & 97.89 \\
\hline Netherlands & 64.20 & 155.15 & 87.37 & 79.04 & 96.80 \\
\hline Sweden & 65.35 & 126.38 & 130.67 & 101.35 & 95.86 \\
\hline Belgium & 35.03 & 76.70 & 74.47 & 55.57 & 91.30 \\
\hline Australia & 66.64 & 89.84 & 116.01 & 127.34 & 88.62 \\
\hline France & 31.05 & 105.71 & 79.80 & 72.21 & 86.23 \\
\hline Spain & 102.00 & 84.69 & 82.95 & 81.84 & 65.65 \\
\hline Ireland & n.a. ${ }^{\mathrm{i}}$ & 82.02 & 53.97 & 27.43 & 53.78 \\
\hline Germany & 22.28 & 65.14 & 42.01 & 41.84 & 51.13 \\
\hline Norway & 29.33 & 38.39 & 61.89 & 68.91 & 49.93 \\
\hline Denmark & 30.39 & 68.12 & n.a.* & n.a.* & 49.25 \\
\hline Portugal & n.a.* & 51.27 & 33.94 & 34.41 & 30.08 \\
\hline Russia & n.a.* & n.a.* & n.a. ${ }^{*}$ & 62.38 & 29.66 \\
\hline Poland & 3.27 & 18.20 & 30.89 & 39.79 & 29.02 \\
\hline Italy & n.a. & 67.30 & 43.08 & 25.18 & 27.46 \\
\hline Turkey & 12.26 & 26.15 & 33.13 & 41.36 & 26.30 \\
\hline Croatia & 3.99 & 12.60 & 28.44 & 42.89 & 21.98 \\
\hline Greece & n.a.* & n.a.* & 58.57 & 22.58 & 21.56 \\
\hline Ukraine & n.a.* & n.a.* & n.a. ${ }^{*}$ & 28.51 & 20.10 \\
\hline Czech Republic & 15.43 & 15.85 & 25.65 & 21.60 & 20.03 \\
\hline Bulgaria & 0.45 & 0.98 & 17.05 & 14.77 & 16.94 \\
\hline Cyprus & n.a.* & n.a.* & n.a. ${ }^{*}$ & 27.07 & 13.94 \\
\hline Estonia & 0.0 & 32.50 & 25.10 & 12.00 & 12.15 \\
\hline Lithuania & 2.00 & 13.90 & 31.50 & 15.60 & 9.40 \\
\hline Slovak Republic & 4.67 & 1.50 & 3.93 & 4.67 & 6.95 \\
\hline Romania & 0.30 & 0.97 & 15.91 & 8.45 & 6.41 \\
\hline Macedonia & n.a.* & 0.19 & 10.32 & 6.91 & 5.81 \\
\hline Latvia & 0.20 & 7.20 & 15.80 & 5.20 & 5.70 \\
\hline
\end{tabular}

The turnover rate, which is calculated as the market turnover and market capitalization ratio, allows the assessment of market liquidity, indicating how often shares traded on average per year. The highest liquidity is observed in the United States, Turkey, Italy, Germany, Switzerland, Australia markets. Baltic stock market trading activity is quite low (about 5-15\%). Estonia and Latvia is ahead of the market of Lithuania (see Fig. 3). 


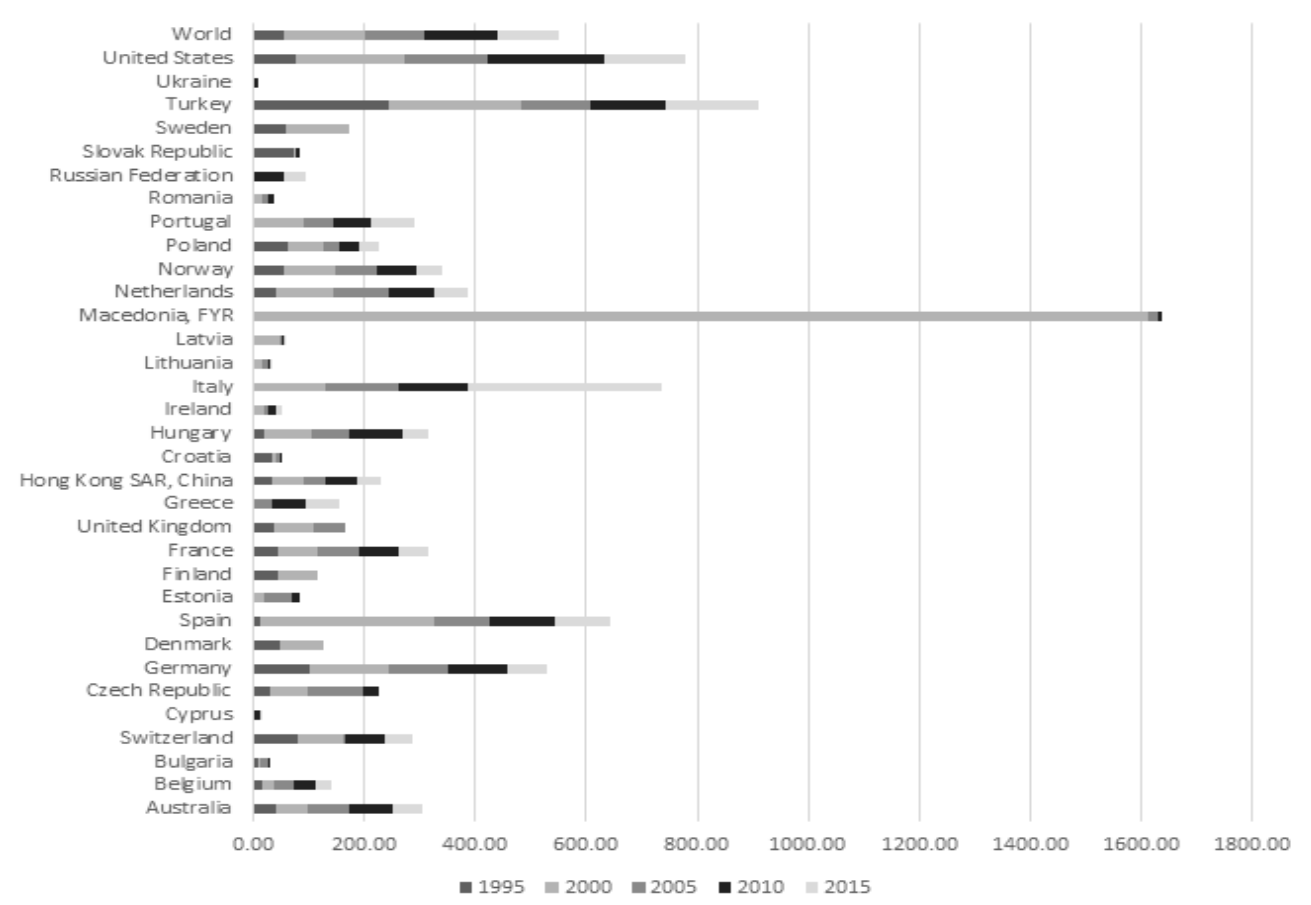

Fig. 3. Stock trading, turnover ratio (\%)

(Source: prepared by the authors, according to World Bank data 2016)

The largest number of listed companies have the United States, Spain, Great Britain, Hong Kong, Australia and France (Fig. 4). Increased number of listed companies lead to more sophisticated stock selection for investment portfolio formation, but at the same time gives for investor a broader range of market opportunities.

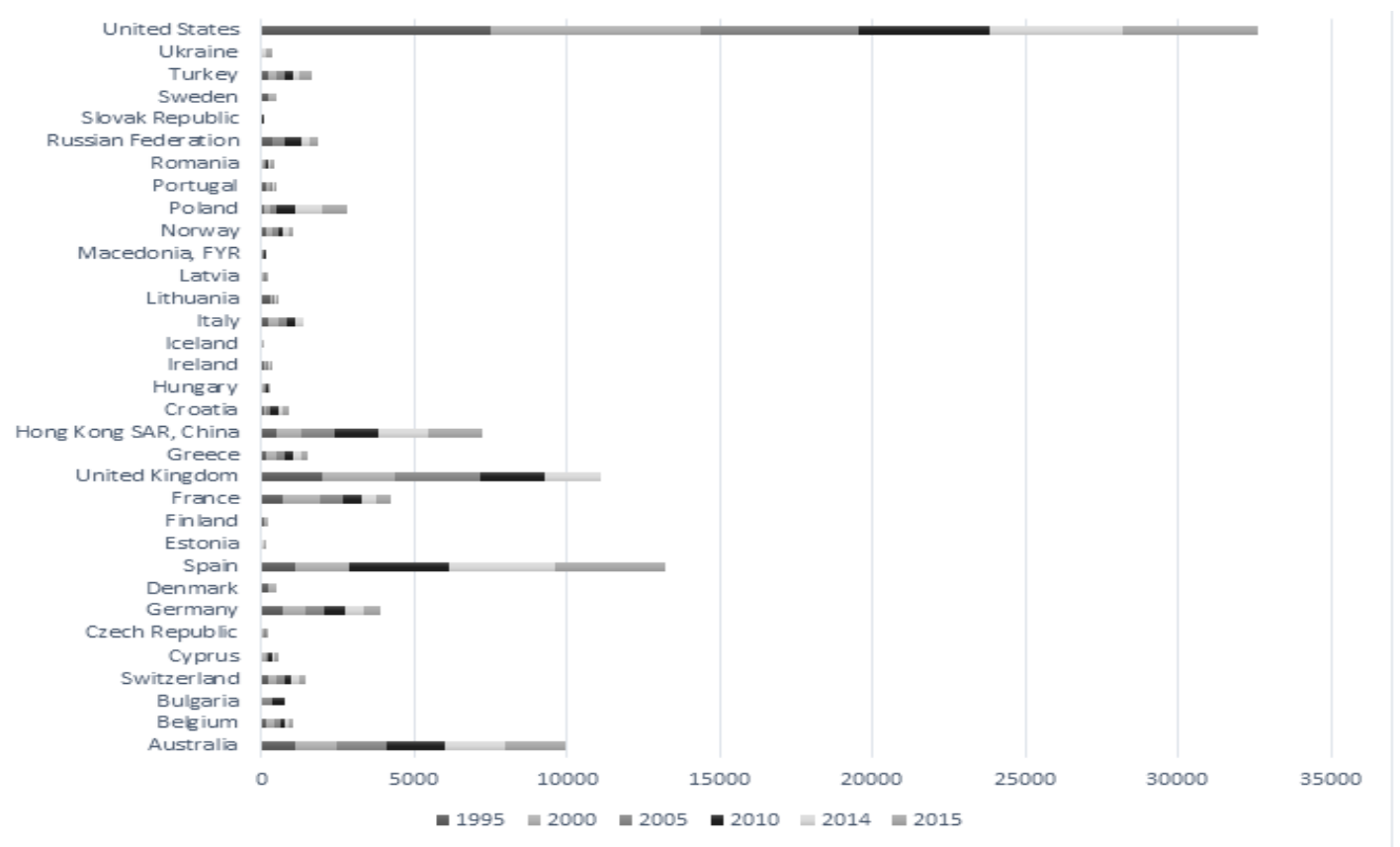

Fig. 4. The number of listed companies

(Source: prepared by the authors, according to World Bank data 2016)

For detailed analysis of financial markets and in order to diversify investment portfolio, it will be evaluated the indexes of eleven markets during the period of 2005-2015: US (Nasdaq index), Australia (ASX200), Belgium (BFX), Denmark (OMX Copenhagen), Greece (GD.AT), Hong Kong (HIS), Spain (IBEX35), Sweden (OMX), Swiss (SSMI), Germany (DAX), France (CAC 40) markets. The markets were assessed according to their profitability and risk (standart deviation of weekly closed price changes). 


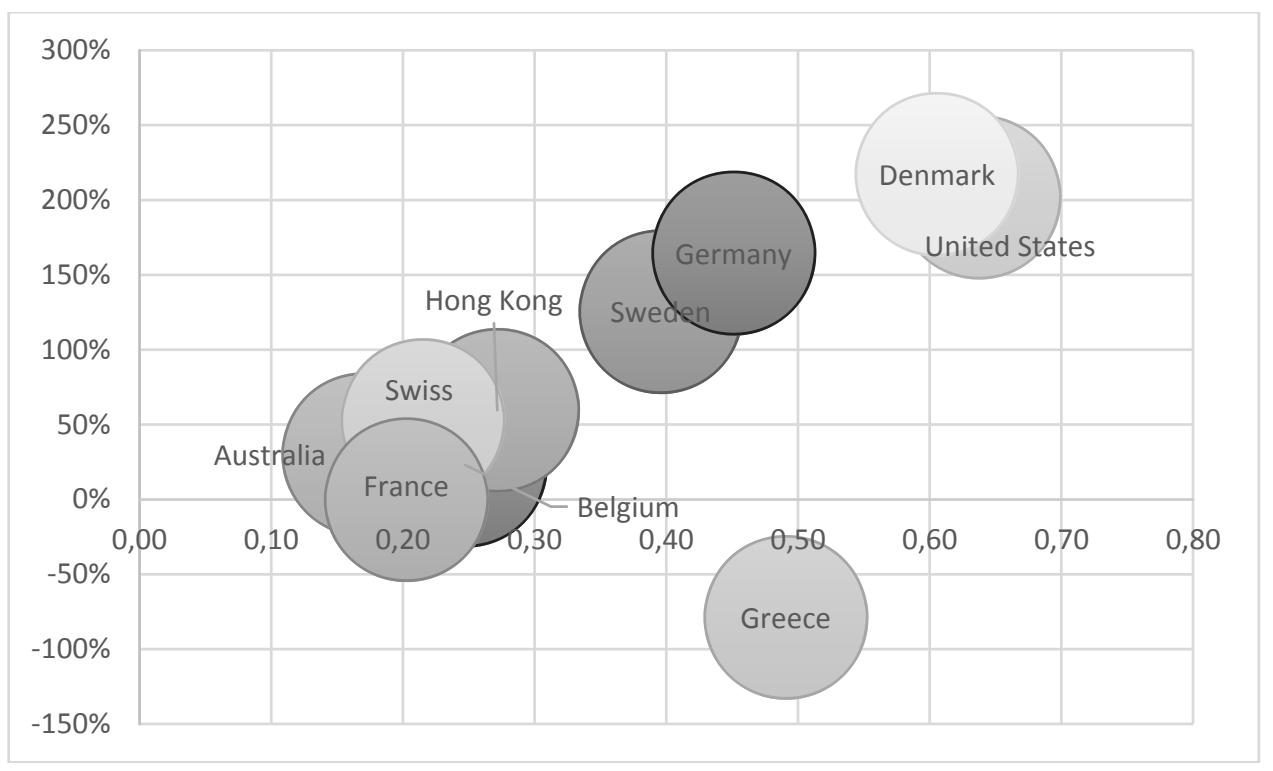

Fig. 5. The evaluation of markets during 2005-2015 periods (Source: compiled by authors)

According to the profitability and risk map of stock markets (see Fig. 5), we can see that United States and Denmark markets was the most profitable, but the degree of risk also was the highest. The most stable markets for investment portfolio formation with average level of risk and profitability are Germany and Sweden. For investors that are more conservative will be very suitable France, Swiss, Australia and Hong Kong markets. The Greece market in this period is nor very suitable for investments.

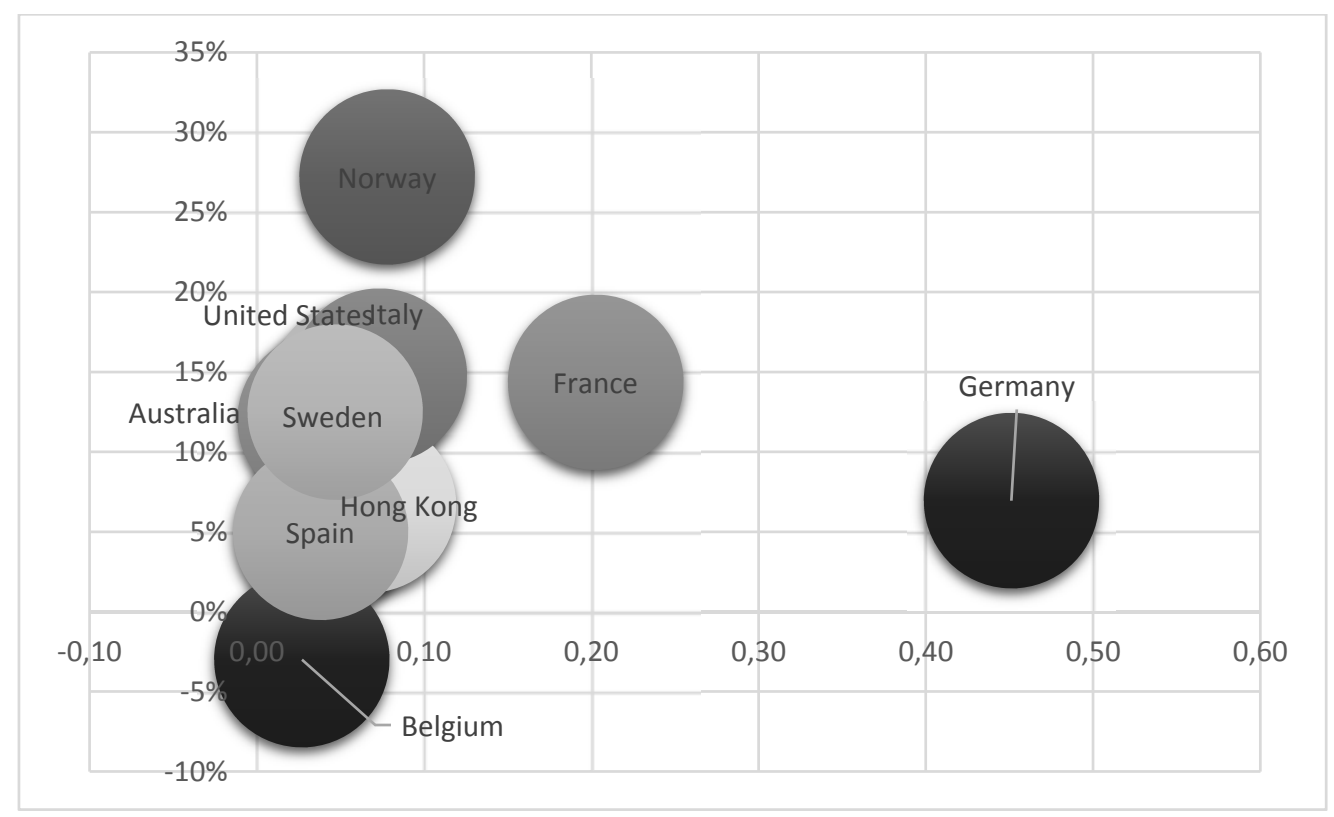

Fig. 6. The evaluation of markets during 2016 years

(Source: compiled by authors)

In order to have more reliable resuts, the profitability and risk in 2016 years also was calculated for the same markets (see Fig. 6). The highest positive investment return have Norway, Italy, France, United States, Sweden and Australia markets, the negative investment return $(-3 \%)$ has only Belgium market. The Germany and France markets has the biggest index price fluctuations during 2016 years.

In order to evaluate financial markets and detect, what opportunities the markets offer for investors, the part of evaluation was based on the view that assumption of the financial rate of return on assets is the possibilities probability distribution. 
Table 2. The highest probability distributions of the markets (Source: compiled by authors)

\begin{tabular}{lll}
\hline \multicolumn{1}{c}{ Market (index) } & \multicolumn{1}{c}{$2005-2015$} & \multicolumn{1}{c}{2016} \\
\hline USA (NDX) & Gamma $(0.74,0.32,2.21)$ & Probability distribution \\
Germany (DAX) & Erlang $(0.08,21.00)$ & Pareto $(55.83)$ \\
France (CAC 40) & Pareto $(25.47)$ & Log Normal $(0.00,0.07,0.06)$ \\
Switzerland (SSMI) & Erlang $(0.03,40.00)$ & Gumbel $(0.30,1.03)$ \\
Sweden (OMX) & Erlang $(0.06,27.00)$ & Pareto $(43.48)$ \\
Belgium (BFX) & Erlang $(0.04,23.00)$ & Gamma Invertida $(1520.34,1595,52)$ \\
Australia (ASX200) & Erlang $(0.02,71.00)$ & Beta $(1.82,1.10,0.95,1.12)$ \\
Spain (IBEX35) & Potencia $(0.51)$ & GammaInvertida $(919.12,947.69)$ \\
Hong Kong (HIS) & Erlang $(0.04,38.00)$ & Pareto $(29.27)$ \\
Denmark (OMX Copenhagen) & LogNormal $(0.00,0.36,0,24)$ & Gama Invertida $(0.01,2.00)$ \\
Greece (GD.AT) & Potencia $(1.00)$ & Uniforme Entera $(-22.0000,14.0000)$ \\
\hline
\end{tabular}

The modelling of financial markets (optimization of utility function) has been used in this stage of financial markets' analysis. The historical data (close price of market index) of markets and the percentage data of weekly changes were used for markets' testing by "Simulacion" programme.

The maximum utility possibilities of all markets and possibilities that have the biggest probability in distribution have been described (i.e. obedient to) with sufficient accuracy and reliability by the following continuous and discrete probability distributions: Erlang, Gumbel, Potencia, Gama Invertida, Uniforme Entera, LogNormal, Beta and Pareto (see Table 2).

The survival function has been used for markets' analysis. The application of this function will allow asses the opportunities, offered by market, according to opportunities, which are provided by guarantee. It is necessary to take into account the profitability, reliability and riskiness in order to select the utility function, which is actually the most useful. According to the calculations, every market can be ranked according to the utility function of the investor point of view (see Fig. 7).

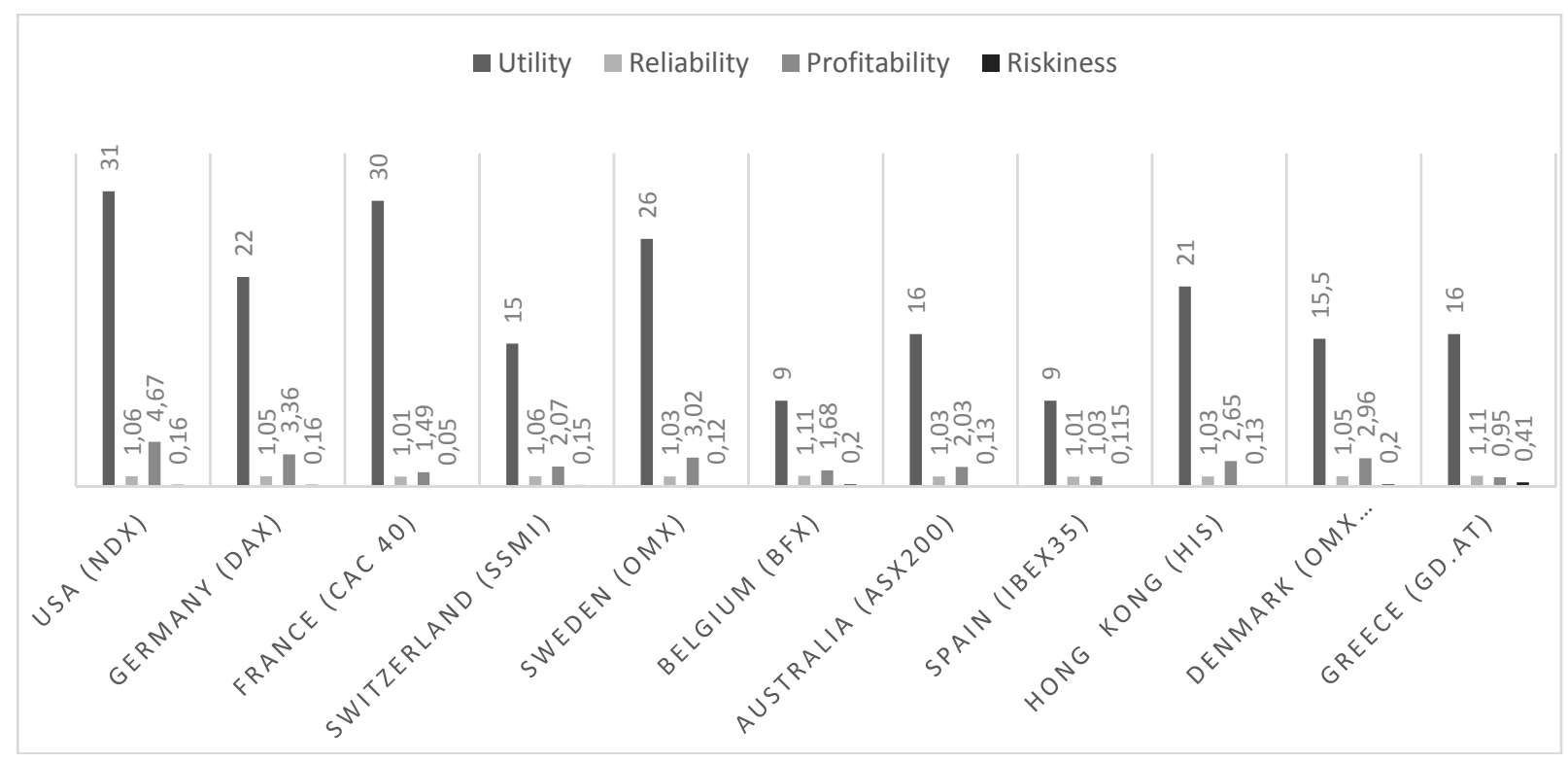

Fig. 7. Markets feasibility study, evaluating their efficiency, reliability, profitability and riskiness (Source: compiled by authors)

It is possible to evaluate all of the selected markets taking into account all the criteria of utility function: efficiency, profitability, reliability and riskiness. However, it is sufficiently difficult to classify markets into more or less attractive for investors having all results. 

done:

After processing the previously received market test results (see Fig. 7), the following generalizations can be

1. The USA, France and Sweden markets can be assessed as the most attractive to the investor by utility indicator. The utility indicators of Spain and Belgium stock markets are the lowest compared with other markets.

2. The Switzerland and USA markets are the most reliable, the least reliable - France and Spain markets.

3. The German, USA and Sweden markets are the safest and generate stable investment return, evaluating markets according to profitability and risk level.

4. The evaluation of four criteria: efficiency, reliability, profitability and riskiness, allows excluding three the most attractive markets for investors - USA, Germany and Sweden markets.

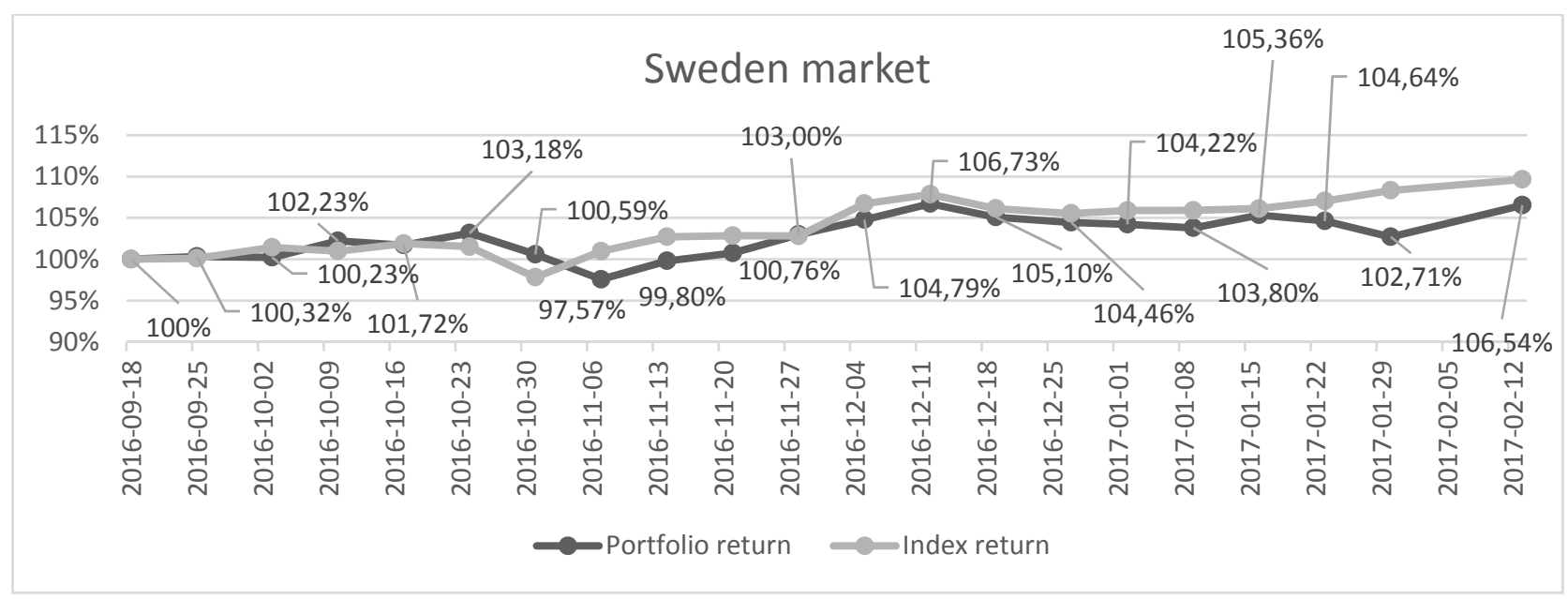

Fig. 8. Investment portfolio results in Sweden (OMX Stockholm) market

(Source: prepared by the authors, based on research results)

Using the result of markets analysis, the authors try to test Sweden market in real time conditons (using DnB Trade platform). The testing was held from September of 2016 till now. The portfolio return during this period is $6,54 \%$, the index return is $9,66 \%$ (see Fig. 8).

Since investment portfolio testing under real conditions has been carried out only for five months, it is difficult to make an unambiguous conclusion summarizing the results, but compared with the index return, it can be said that so far, the market selection scheme has proven.

\section{Conclusions}

For market analysis scientist use technical and fundamental analysis, efficient market hyphotesis and many other methods. They have their own advantages and disadvantages. The authors of the paper proposed their own scheme for market selection, which includes the profitability and risk evaluation of market indexes, market capitalization and turnover ratio evaluation, the probabilities distribution identification and markets feasibility study, evaluating their utility and reliability.

The level of utility indicator was sufficiently effective and ranked the selected markets by potentially best investment opportunities for investors. The application of utility function, taking into account the reliability, utility, profitability and risk, shoul led to a more sustainable financial investments result in financial markets in long period.

The authors perform the market anlysis from 33 different stock markets. The evaluation period was ten years. According to the profitability and risk map of stock markets, the authors identified that the most stable markets for investor are Germany and Sweden. The evaluation according to utility function shows that most attractive markets for investors - USA, Germany and Sweden markets. It should be noted that USA market is the market with biggest capitalization and the highest profitability, so takes to investors more opportunities for investment portfolio formation.

The authors test formed markets selection scheme in Sweden market. They create the portfolio from this market stocks and trade it in real time conditions, using $\mathrm{DnB}$ Trade platform. The portfolio return during investment period is $6,54 \%$, portfolio was viable despite market specifics, so it can be argued that the market selection scheme, proposed by authors, works in stock markets, which approves the comparison of investment results with index. 


\section{References}

Albadvi, A.; Chaharsooghi, S. K.; Esfahanipour, A. 2007. Decision making in stock trading: an application of PROMETHEE. European Journal of Operational Research 177: 673-683. https://doi.org/10.1016/j.ejor.2005.11.022

Ataullah, A.; Cockerill, T.; Le, H. 2004. Financial liberalization and bank efficiency: a comparative analysis of India and Pakistan, Applied Economics 36: 1915-1924. https://doi.org/10.1080/000368404200068638

Bae, K.; Ozoguz, A.; Tan, H.; Wirjanto, T. S. 2012. Do foreigners facilitate information transmission in emerging markets, Journal of Financial Economics 105: 209-227. https://doi.org/10.1016/j.jfineco.2012.01.001

Banz, R. 1981. The relationship between return and market value of common stocks, Journal of Financial Economics 9(1): 3-18. https://doi.org/10.1016/0304-405X(81)90018-0

Bayramoglu1, M. F.; Hamzacebi, C. 2016. Stock Selection Based on Fundamental Analysis Approach by Grey relational analysis: a case of Turkey, International Journal of Economics and Finance 8(7): 178-184.

Cajueiro, D. O.; Gogas, P.; Tabak, B. M. 2009. Does financial market liberalization increase the degree of market efficiency? The case of the Athens stock exchange, International Review of Financial Analysis 18: 50-57. https://doi.org/10.1016/j.irfa.2008.11.004

Cibulskienė, D.; Grigaliūnienè, Ž. 2006. Fundamentinių ir techninių veiksnių įtaka vertybinių popierių portfelio formavimui, Ekonomika ir vadyba: aktualijos ir perspektyvos 2(7): 25-34.

Daniel, M.; Neves, R. F.; Horta, N. 2017. Company event popularity for financial markets using Twitter and sentiment analysis, Expert Systems with Applications 71(2017): 111-124. https://doi.org/10.1016/j.eswa.2016.11.022

Fama, E. F. 1965. The behavior of stock - market prices, Journal of Business 38(1): 34-105. https://doi.org/10.1086/294743

Fama, E. F. 1970. Efficient capital markets: a review of theory and empirical work, The Journal of Finance 25: $383-470$. https://doi.org/10.2307/2325486

Gorgulho, A.; Neves, R.; Horta, N. 2011. Applying a GA kernel on optimizing technical analysis rules for stock picking and portfolio composition, Expert systems with Applications 38(11): 14072-14085.

Hooy, C.; Lim, K. 2013. Is market integration associated with informational efficiency of stock markets?, Journal of Policy Modelling 35: 29-44. https://doi.org/10.1016/j.jpolmod.2012.09.002

Jeffrey, F.; Westerfield, R. 1989. Is there a monthly effect in stock market returns?: Evidence from foreign countries, Journal of Banking and Finance 13: 641-650.

Keim, D. 1983. Size-related anomalies and stock return seasonality: further empirical evidence, Journal of Financial Economics 12: 13-32. https://doi.org/10.1016/0304-405X(83)90025-9

Kim, E. H.; Singal, V. 2002. The fear of globalizing capital markets, Emerging Markets Review 1: $183-198$. https://doi.org/10.1016/S1566-0141(00)00014-5

Kirkpatrick, C. D.; Dahlquist, J. R. 2016. Technical analysis: the complete resource for financial market technicians. $3^{\text {rd }}$ ed. FT Press. 704 p.

Masry, M. 2017. The impact of technical analysis on stock returns in an emerging capital markets (ECM's) country: theoretical and empirical study, International Journal of Economics and Finance 9(3): 91-107. https://doi.org/10.5539/ijef.v9n3p91

Mittal, S. K.; Jain, S. 2009. Stock market behaviour: evidences from Indian market, The Journal of Business Perspective 13(3): 2029. https://doi.org/10.1177/097226290901300302

Narayan, P. K.; Narayan, S.; Sharma, S. 2013. An analysis of commodity markets: what gain for investors?, Financial Econometrics Series swp 2013/02: 1-45.

Roll, R. 1983. The turn-of-the-year effect and the return premia of small firms, Journal of Portfolio Management 9: 18-28. https://doi.org/10.3905/jpm.1983.18

Rozeff, M. S.; Kinney, W. R. 1976. Capital market seasonality: The case of stock returns, Journal of Financial Economics 3: 379-402. https://doi.org/10.1016/0304-405X(76)90028-3

Rutkauskas, A. V. 2000. Formation of adequate investment portfolio for stochasticity of profit possibilities, Property Management 4(2): 100-115.

Rutkauskas, A. V.; Kvietkauskienė, A. 2012. Successful investment - market behavior and investing intelligence compatibility result, in The Conference Proceedings Contemporary Issues in Business, Management and Education'2012, 15 November 2012, Vilnius, Lithuania, 170-182 [online], [cited 15 January 2017]. Available from Internet: http://cbme.vgtu.lt/index.php/cbme/cbme_2012/schedConf/presentations

Rutkauskas, A. V.; Stasytytė, V. 2011. Optimal portfolio search using efficient surface and three-dimensional utility function, Technological and Economic Development of Economy 17(2): 305-326. https://doi.org/10.3846/20294913.2011.580589

Silva, A.; Neves, R.; Horta, N. 2015. A hybrid approach to portfolio composition based on fundamental and technical indicators, Expert Systems with Applications 42(4): 2036-2048. https://doi.org/10.1016/j.eswa.2014.09.050

Steeley, J. M. 2001. A note on information seasonality and the disappearance of the weekend effect in the UK stock market, Journal of Banking \& Finance 25(10): 1941-1956. https://doi.org/10.1016/S0378-4266(00)00167-9

Stickel, S. E. 1995. The anatomy of the performance of buys and sells recommendations, Financial Analyst Journal Sept.-Oct.: 25-39.

Womack, K. L. 1996. Do brokerage analysts' recommendations have investment value?, Journal of Finance 51(1): 137-167. https://doi.org/10.1111/j.1540-6261.1996.tb05205.x

World bank data [online], 2016 [cited 5 December 2016]. Available from Internet: http://data.worldbank.org/

Шевченко, И. Г. 2001. Стратегический анализ рынка акиионерного капитала в России [Shevchenko, I. G. Strategicheskij analiz rynka akcyonernogo kapitala v Rosiji]. Москва: Эфимориал УРСС. 